\title{
Improved spectrophotometric assay for lytic polysaccharide monooxygenase
}

\author{
Erik BresImayr ${ }^{1,2}$, Sarah Daly ${ }^{1}$, Alen Požgajčić ${ }^{1,3}$, Hucheng Chang ${ }^{1}$, Tonči Rezić ${ }^{3}$, Chris Oostenbrink ${ }^{2}$
} and Roland Ludwig ${ }^{1 *}$ (D)

\begin{abstract}
Background: The availability of a sensitive and robust activity assay is a prerequisite for efficient enzyme production, purification, and characterization. Here we report on a spectrophotometric assay for lytic polysaccharide monooxygenase (LPMO), which is an advancement of the previously published 2,6-dimethoxyphenol (2,6-DMP)-based LPMO assay. The new assay is based on hydrocoerulignone as substrate and hydrogen peroxide as cosubstrate and aims toward a higher sensitivity at acidic $\mathrm{pH}$ and a more reliable detection of LPMO in complex matrices like culture media.

Results: An LPMO activity assay following the colorimetric oxidation of hydrocoerulignone to coerulignone was developed. This peroxidase activity of LPMO in the presence of hydrogen peroxide can be detected in various buffers between $\mathrm{pH} 4-8$. By reducing the substrate and cosubstrate concentration, the assay has been optimized for minimal autoxidation and enzyme deactivation while maintaining sensitivity. Finally, the optimized and validated LPMO assay was used to follow the recombinant expression of an LPMO in Pichia pastoris and to screen for interfering substances in fermentation media suppressing the assayed reaction.
\end{abstract}

Conclusions: The biphenol hydrocoerulignone is a better substrate for LPMO than the monophenol 2,6-DMP, because of a $\sim 30$ times lower apparent $K_{\mathrm{M}}$ value and a $160 \mathrm{mV}$ lower oxidation potential. This greatly increases the measured LPMO activity when using hydrocoerulignone instead of 2,6-DMP under otherwise similar assay conditions. The improved activity allows the adaptation of the LPMO assay toward a higher sensitivity, different buffers and $\mathrm{pH}$ values, more stable assay conditions or to overcome low concentrations of inhibiting substances. The developed assay protocol and optimization guidelines increase the adaptability and applicability of the hydrocoerulignone assay for the production, purification, and characterization of LPMOs.

Keywords: Activity assay, 2,6-Dimethoxyphenol, Hydrocoerulignone, Hydrogen peroxide, Inhibitors, Lytic polysaccharide monooxygenase, Peroxidase activity

\section{Background}

The number of characterized lytic polysaccharide monooxygenases (LPMO) has been steadily increasing over the last years and resulted in the discovery of new substrate specificities and classification of LPMOs by the Carbohydrate-Active enZYme (CAZy) database or the Enzyme Commission (EC). Currently, known LPMO activities are allocated to CAZy auxiliary

\footnotetext{
*Correspondence: roland.ludwig@boku.ac.at

${ }^{1}$ Biocatalysis and Biosensor Laboratory, Department of Food Science and Technology, BOKU-University of Natural Resources and Life Sciences, Muthgasse 18,1190 Vienna, Austria

Full list of author information is available at the end of the article
}

activities AA9 [EC 1.14.99.54 lytic cellulose monooxygenase (C1-hydroxylating) and EC 1.14.99.56 lytic cellulose monooxygenase (C4-dehydrogenating)], AA10 (EC 1.14.99.53, lytic chitin monooxygenase), AA11, AA13 (EC 1.14.99.55 lytic starch monooxygenase), AA14, AA15, and AA16 [1-4] all involved in the degradation of polysaccharides [5]. The search for novel LPMOs is driven by the need to improve industrial biomass utilization by reducing the time of hydrolysis and increasing the specificity of the depolymerization process. Before assessing the properties of a newly discovered LPMO, it has to be recombinantly produced and purified. A fast and sensitive assay is therefore a necessity to optimize 
fermentation and purification protocols or to simplify its biochemical characterization, e.g., deactivation studies. Ideally, such an assay should detect LPMOs from various classes without being limited by the use of class-specific polysaccharide substrates.

Based on a study, in which Bissaro et al. [6] demonstrated that $\mathrm{H}_{2} \mathrm{O}_{2}$ is a cosubstrate of LPMOs, we previously developed a colorimetric assay that employs LPMO's active site copper center in a peroxidase-like reaction to convert 2,6-DMP into the highly colored product coerulignone [7]. The conversion of 2,6-DMP by LPMO, a small phenolic compound occurring in lignin, is not unexpected considering that LPMOs can also oxidize similar lignin degradation products to obtain the necessary electron for its active site copper activation [8-10]. The formation of coerulignone involves two steps and starts with the oxidation of two 2,6-DMP molecules, which spontaneously dimerize to a dimer (hydrocoerulignone) and cannot be followed in the visible range. In the second step, the formed hydrocoerulignone molecule is oxidized to the chromogenic compound coerulignone. The stoichiometry of the reaction 2,6-DMP $\rightarrow$ hydrocoerulignone $\rightarrow$ coerulignone is $2: 1: 1$, and in total, two $\mathrm{H}_{2} \mathrm{O}_{2}$ molecules are consumed. The molar absorption coefficient of coerulignone is $\varepsilon_{469}=53,200 \mathrm{M}^{-1} \mathrm{~cm}^{-1}$, which makes this reaction product suitable for a sensitive LPMO assay. However, 2,6-DMP is a poor substrate for LPMO because of two reasons: (1) the apparent $K_{\mathrm{M}}$ value of LPMO for the monophenol 2,6-DMP is very high $(\sim 100 \mathrm{mM},[7])$ and (2) the oxidative potential of 2,6DMP is close to the midpoint potential of LPMOs $(-50$ to $+121 \mathrm{mV}$ vs. $\mathrm{Ag} \mid \mathrm{AgCl},[11])$, which reduces the driving force of the reaction, especially at acidic $\mathrm{pH}$ and low 2,6-DMP concentrations [7]. A similar effect on the efficiency of a reductant in regard to redox potential and $\mathrm{pH}$ has been observed for 2,3-dihydroxybenzoic acid [12].

The 2,6-DMP assay has been used in different studies to detect LPMOs peroxidase activity [13-15] to compare different LPMO fractions during purification [16] or to study the thermal stability of an LPMO [17]. However, some users have indicated that the 2,6-DMP assay does not work for certain LPMOs. We therefore want to point out that, although we have found this peroxidase activity with all LPMOs we tested so far, this is no guarantee that all LPMOs can be screened or detected. Also the wish for an easier, more sensitive and more robust assay was addressed. We observed in preliminary studies that the reaction intermediate hydrocoerulignone (also a compound derived from lignin) can replace 2,6-DMP as a substrate in the LPMO activity assay. The oxidation of 2,6-DMP to hydrocoerulignone was found to be the rate-limiting step in the reaction and the rate of hydrocoerulignone conversion was $\sim 15$

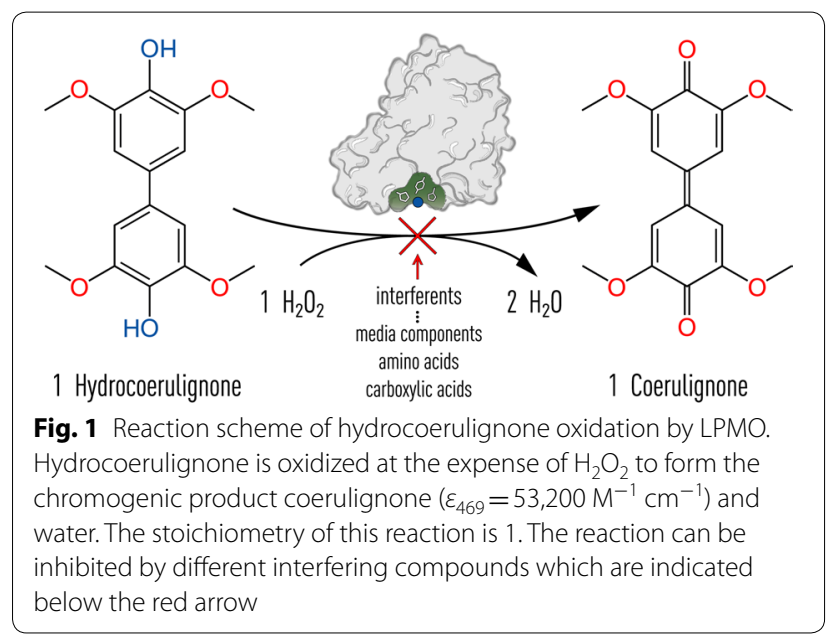

times faster compared to 2,6-DMP. An activity assay for LPMO employing hydrocoerulignone should therefore be suitable to detect LPMO activity at a lower enzyme concentration and at slightly acidic, more physiological $\mathrm{pH}$ conditions (e.g., $\mathrm{pH} \sim 5.5$ in wood cell walls, [18]).

The assayed LPMO peroxidase-like reaction depends on the initial reduction of the LPMO copper active site from its resting state $\mathrm{Cu}(\mathrm{II})$ to $\mathrm{Cu}(\mathrm{I})$ by hydrocoerulignone and the subsequent binding of $\mathrm{H}_{2} \mathrm{O}_{2}$ to form the chromogenic compound coerulignone with a stoichiometry of 1:1 (Fig. 1). However, it is obvious that the surface exposed copper active site is not protected from metal-chelating molecules. When testing LPMO activity with 2,6-DMP, we observed inhibition by different buffer species, e.g., citric acid or histidine. Therefore, different media components or substances secreted by fungi, like amino acids, salts/ions, and carboxylic acids were screened for an inhibitory effect on the assay. Several rounds of optimization were performed on the assay to find robust and sensitive assay parameters and conditions. The selection of the assay buffer, its concentration, and $\mathrm{pH}$, the substrate and cosubstrate concentration, as well as the applied LPMO concentration/ activity is described in the following sections before a protocol of the developed assay is presented. Insights into LPMO's peroxidase activity are summarized in a guideline on how to modify the assay for maximum sensitivity or how to troubleshoot potential problems.

\section{Results}

Assay preparations and initial measurements

The stoichiometry of the assayed reaction (Eq. 1) has been established in previous publications [7, 19],

1 hydrocoerulignone $+1 \mathrm{H}_{2} \mathrm{O}_{2} \rightarrow 1$ coerulignone $+2 \mathrm{H}_{2} \mathrm{O}$ 
where hydrocoerulignone is the first reaction product of the LPMO catalyzed conversion of 2,6-dimethoxyphenol (2,6-DMP) to the colorimetric product coerulignone (Eq. 2),

$$
2 \text { 2, 6-DMP }+1 \mathrm{H}_{2} \mathrm{O}_{2} \rightarrow 1 \text { hydrocoerulignone }+2 \mathrm{H}_{2} \mathrm{O}
$$

which is followed by the reaction given in Eq. 1 to result in the overall reaction (Eq. 3).

$$
2 \text { 2, 6-DMP }+2 \mathrm{H}_{2} \mathrm{O}_{2} \rightarrow 1 \text { coerulignone }+4 \mathrm{H}_{2} \mathrm{O}
$$

The molar absorption coefficient of hydrocoerulignone at $280 \mathrm{~nm}$ was determined to be $16,260 \mathrm{M}^{-1} \mathrm{~cm}^{-1}$ (Additional file 1). The reaction rate of LPMO with hydrocoerulignone is $\sim 15$ times faster compared to 2,6-DMP [7]. Reasons could be a better binding to the active site of LPMO, which is demonstrated by a lower apparent $K_{\mathrm{M}}$ value for hydrocoerulignone than for 2,6-DMP (data shown below), or a more favorable, lower redox potential.

The oxidative onset potential of hydrocoerulignone (Fig. 2) is at pH 6.0 about $160 \mathrm{mV}$ lower than that of 2,6-DMP. The $\mathrm{pH}$-dependent increase in the

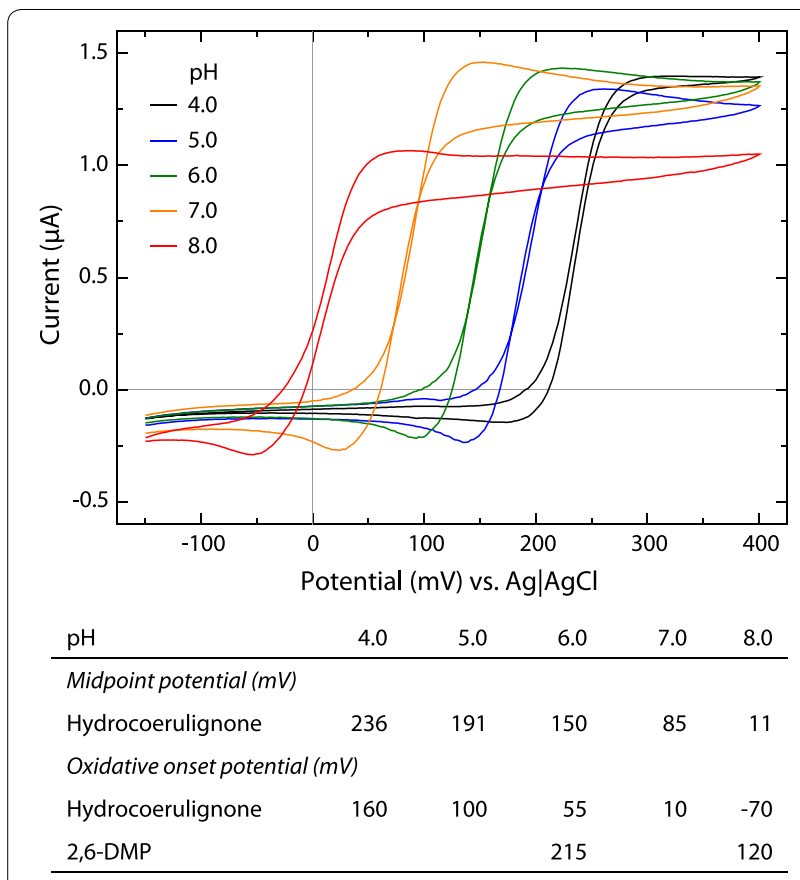

Fig. 2 Determination of the hydrocoerulignone midpoint potentials and oxidative onset potentials by cyclic voltammetry using $500 \mu \mathrm{M}$ hydrocoerulignone in $50 \mathrm{mM}$ sodium phosphate buffer between $\mathrm{pH} 4.0$ and 8.0. At pH 7.0 and especially pH 8.0, the autoxidation and polymerization of hydrocoerulignone were observed. The data extracted from the cyclic voltammograms are given in the table below and are compared to data for 2,6-DMP (300 $\mu \mathrm{M})$ from Breslmayr et al. [7] hydrocoerulignone-coerulignone midpoint potential and onset potential follow roughly the Nernst equation, but $\Delta E$ is smaller than $59 \mathrm{mV}$ below $\mathrm{pH} 6$ and larger above. At pH 6.0 and a $500 \mu \mathrm{M}$ concentration, the oxidative onset potential of hydrocoerulignone is $55 \mathrm{mV}$ vs. $\mathrm{Ag} \mid \mathrm{AgCl}$. In comparison, at $\mathrm{pH} 6.0$ and a $300 \mu \mathrm{M}$ concentration, the oxidative onset potential of 2,6-DMP is $215 \mathrm{mV}$ vs. $\mathrm{Ag} \mid \mathrm{AgCl}$ [7]. The higher oxidation potentials at acidic $\mathrm{pH}$ (e.g., hydrocoerulignone at $\mathrm{pH} 4.0$ is $236 \mathrm{mV}$ vs. $\mathrm{Ag} \mid \mathrm{AgCl})$ might be very close to or exceed the midpoint potential of the active site copper and thereby limit LPMO activity to less acidic $\mathrm{pH}$. The use of the oxidative onset potential for a comparison with 2,6-DMP is necessary as no midpoint potential can be determined for 2,6-DMP. The reason is the non-reversible reaction of 2,6-DMP to hydrocoerulignone and the fast, subsequent reaction of hydrocoerulignone to coerulignone.

\section{LPMO activity is affected by buffer concentration, denticity, and $\mathrm{pH}$}

The $\mathrm{pH}$-dependent activity of LPMO with hydrocoerulignone was measured in different buffers. A general, monotonic increase in activity was observed between $\mathrm{pH} 4-8$. This strong increase in activity, which we correlate to the decrease of the hydrocoerulignone oxidation potential at higher $\mathrm{pH}$ values, made it necessary to use a semilogarithmic scale for the $\mathrm{pH}$ profile (Fig. 3). Several mono-, di-, and tricarboxylic acids, hydroxycarboxylic acids, and phosphoric acids were used as anionic buffer species as well as pyridine, imidazole as cationic buffer species, and histidine as a zwitterion. The denticity of di- and tricarboxylic acids has a strong influence on the LPMO activity. The measured activity is higher in buffers with a lower equivalent of carboxy or hydroxyl groups and decreases in the following order: acetate $>$ succinate $>$ malate $>$ citrate $>$ oxalate (Fig. 3a). In oxalate and citrate buffer, LPMO shows the lowest activity, which at $\mathrm{pH} 6.0$, is 100 -fold and 50 -fold lower, respectively. The low activity can be correlated with the chelating properties of bi- or tridentate anions, which potentially bind to the active site copper in LPMO.

Pyridine- $\mathrm{HCl}$ and imidazole- $\mathrm{HCl}$ as cationic buffers result in LPMO activities as high as in the best anionic buffer sodium acetate (Fig. $3 \mathrm{~b}$ ). The $\mathrm{pH}$ profile of the zwitterion histidine is the only one which shows a low, constantly decreasing activity between $\mathrm{pH} 5.5$ and 7.0, which indicates that the deprotonation of its imidazole ring in combination with the carboxy or amine group of histidine inhibits LPMO activity by a stronger binding to the active site copper atom. Even when avoiding bi- and tridentate buffer species, many buffers can be used. However, we suggest a simple sodium acetate buffer for the 


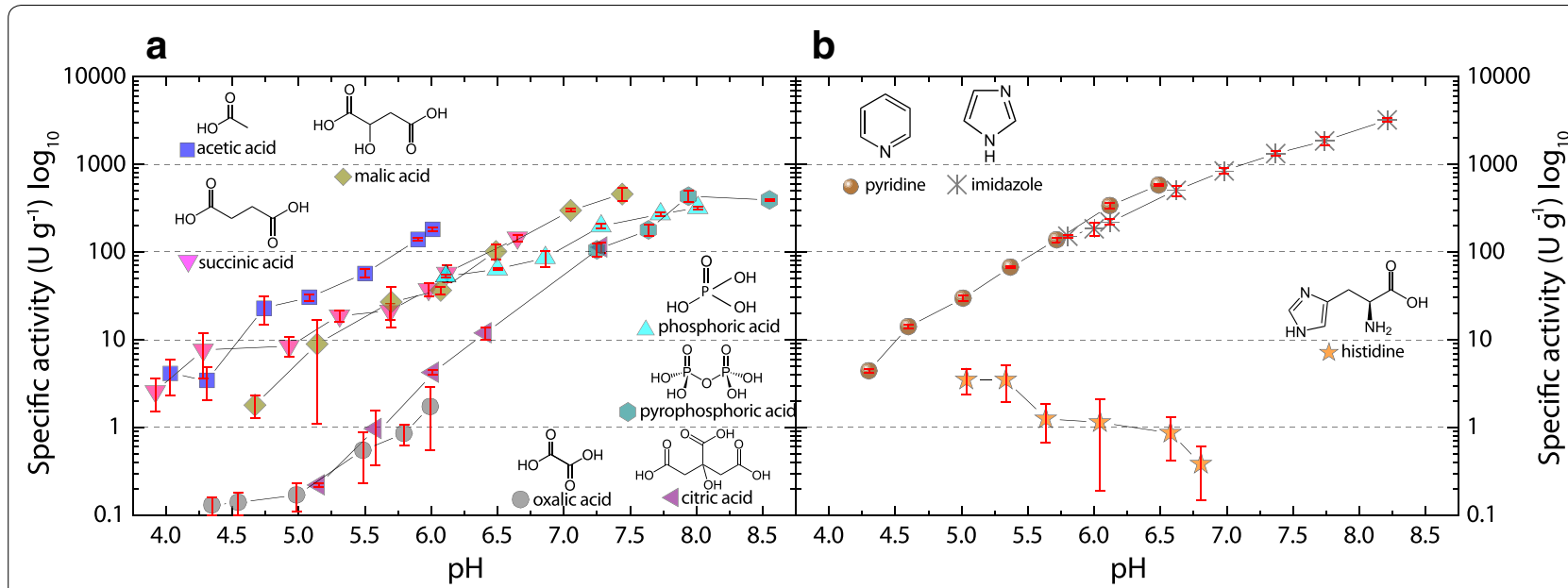

Fig. $3 \mathrm{pH}$ profile of $\mathrm{NCLPMO} 9 \mathrm{C}(0.3 \mu \mathrm{M})$ activity on $1000 \mu \mathrm{M}$ hydrocoerulignone and $100 \mu \mathrm{M} \mathrm{H}_{2} \mathrm{O}_{2}$ in various buffers. a $100 \mathrm{mM}$ carboxylate or phosphate buffers titrated with $\mathrm{NaOH}$ and $\mathbf{b} 100 \mathrm{mM}$ cationic pyridine, imidazole, or histidine buffers titrated with $\mathrm{HCl}$. All data are shown as mean values $( \pm S D)$, from four independent repeats

$\mathrm{pH}$ range from $\mathrm{pH} 4.5-6.0$, or an imidazole- $\mathrm{HCl}$ buffer for enhanced activity in the $\mathrm{pH}$ range from $\mathrm{pH}$ 6.0-8.0.

\section{Determination of steady-state kinetic constants for LPMO}

To evaluate the most useful substrate and cosubstrate concentrations in the assay, the apparent kinetic constants of NcLPMO9C for hydrocoerulignone and $\mathrm{H}_{2} \mathrm{O}_{2}$ were determined (Table 1, Additional file 2). Depending on the selected concentration of the cosubstrate $\mathrm{H}_{2} \mathrm{O}_{2}$ $(3.18-300 \mu \mathrm{M})$ the $K_{\mathrm{M} \text {,app }}$ value for hydrocoerulignone increases from 0.6 to $4.8 \mathrm{mM}$, respectively. The $K_{\mathrm{M} \text {,app }}$ value for the biphenol hydrocoerulignone measured at a cosubstrate concentration of $100 \mu \mathrm{M} \mathrm{H}_{2} \mathrm{O}_{2}$ is $3.6 \mathrm{mM}$, which is much more suitable for the assay than the high $K_{\mathrm{M}}$ value for the monophenol 2,6-DMP $(\sim 100 \mathrm{mM})$ at the same cosubstrate concentration. However, at concentrations above $1 \mathrm{mM}$ hydrocoerulignone, the nonenzymatic oxidation to coerulignone results in an already high reaction background, which reduces the signal-to-noise ratio and prevents kinetic measurements under pseudo-first-order conditions. The highest signal-to-noise ratio was obtained when using $500 \mu \mathrm{M}$ hydrocoerulignone and $100 \mu \mathrm{M} \mathrm{H}_{2} \mathrm{O}_{2}$. The ratio of the blank reaction over the LPMO reaction is given in a spider diagram for hydrocoerulignone concentrations between 62.5 and $2000 \mu \mathrm{M}$ in Additional file 3. For the cosubstrate $\mathrm{H}_{2} \mathrm{O}_{2}$ LPMO shows a much higher affinity. The $K_{\text {M,app }}$ values for $\mathrm{H}_{2} \mathrm{O}_{2}$ at $\mathrm{pH} 6.0$ are between 1.4 and $7.8 \mu \mathrm{M}$ depending on the used hydrocoerulignone concentration (Table 1).

The turnover stability of LPMO in the hydrocoerulignone assay is higher than in the DMP assay. A comparison of the 2,6-DMP assay under standard conditions $(50 \mathrm{mM}$ succinate phosphate buffer, $\mathrm{pH}$ 7.5, $30{ }^{\circ} \mathrm{C}, 1000 \mu \mathrm{M}$ 2,6-DMP, $100 \mu \mathrm{M} \mathrm{H}_{2} \mathrm{O}_{2}$ ) with the hydrocoerulignone assay under standard conditions (100 mM sodium acetate buffer, $\mathrm{pH} 6.0,30{ }^{\circ} \mathrm{C}, 500 \mu \mathrm{M}$ hydrocoerulignone, $100 \mu \mathrm{M} \mathrm{H} \mathrm{H}_{2} \mathrm{O}_{2}$ ) showed that the

Table 1 Kinetic constants of $\mathrm{NCLPMO}$ C for $\mathrm{H}_{2} \mathrm{O}_{2}$ and hydrocoerulignone determined in $50 \mathrm{mM}$ sodium phosphate buffer, pH 6.0

\begin{tabular}{|c|c|c|c|c|c|}
\hline \multicolumn{3}{|l|}{$\mathrm{H}_{2} \mathrm{O}_{2}$ catalytic constants } & \multicolumn{3}{|c|}{ Hydrocoerulignone catalytic constants } \\
\hline Hydrocoerulignone $(\mu \mathrm{M})$ & $K_{\mathrm{M}, \text { app }}(\mu \mathrm{M})$ & $V_{\text {max,app }}\left(\mathrm{U} \mathrm{g}^{-1}\right)$ & $\mathrm{H}_{2} \mathrm{O}_{2}(\mu \mathrm{M})$ & $K_{\mathrm{M}, \text { app }}(\mu \mathrm{M})$ & $V_{\text {max,app }}\left(\mathrm{U} \mathrm{g}^{-1}\right)$ \\
\hline 2000 & $7.8 \pm 0.8$ & $194.2 \pm 4.2$ & 300 & $4800 \pm 900$ & $644 \pm 93$ \\
\hline 1000 & $4.3 \pm 0.6$ & $118.1 \pm 2.8$ & 100 & $3600 \pm 500$ & $534 \pm 58$ \\
\hline 500 & $4.2 \pm 0.5$ & $63.5 \pm 1.2$ & 50 & $2100 \pm 200$ & $327 \pm 21$ \\
\hline 250 & $2.7 \pm 0.3$ & $36.4 \pm 0.7$ & 25 & $1700 \pm 300$ & $255 \pm 28$ \\
\hline 125 & $1.7 \pm 0.5$ & $19.1 \pm 0.6$ & 12.5 & $2000 \pm 400$ & $250 \pm 29$ \\
\hline \multirow[t]{2}{*}{62.5} & $1.4 \pm 0.2$ & $12.5 \pm 0.2$ & 6.25 & $1300 \pm 400$ & $151 \pm 22$ \\
\hline & & & 3.18 & $600 \pm 100$ & $71 \pm 6$ \\
\hline
\end{tabular}


2,6-DMP activity of NcLPMO9C decreased noticeable after $5 \mathrm{~min}$ in which it produces $4 \mu \mathrm{M}$ coerulignone per $\mu \mathrm{M}$ of enzyme. Based on the reaction stoichiometry, this results in a total turnover of $8 \mathrm{H}_{2} \mathrm{O}_{2}$ molecules per enzyme. In contrast, NcLPMO9C in the hydrocoerulignone assay was stable for more than $10 \mathrm{~min}$ and produced $61 \mu \mathrm{M}$ coerulignone per $\mu \mathrm{M}$ of enzyme. This results in a total turnover of $61 \mathrm{H}_{2} \mathrm{O}_{2}$ molecules, which is $\sim 8$ times higher than in the 2,6-DMP assay.

The peroxidase activity of six different LPMOs from two different organisms was assayed with hydrocoerulignone. The specific activity of purified enzyme preparations was measured at standard conditions with hydrocoerulignone and 2,6-DMP assay for Neurospora crassa LPMO9C, LPMO9E, and LPMO9J and for Crassicarpon hotsonii (syn. Myriococcum thermophilum) LPMO (gene identifier) Myrth2p4_000359, Myrth2p4_004260, and Myrth2p4_006403 (Table 2). All LPMOs were active with both assays and the determined specific activities show a faster reaction with hydrocoerulignone.

\section{Linear range and limit of detection}

A recovery study was performed to obtain the assay's limit of detection for LPMO at $\mathrm{pH}$ 6.0, a commonly observed $\mathrm{pH}$ in fungal cultures (Fig. 4). NcLPMO9C was added to the assay in a concentration between 0.01 and $6.00 \mu \mathrm{M}$. The measured rates from the initial $300 \mathrm{~s}$ of the reaction are plotted versus the added NcLPMO9C concentrations. The activity was directly proportional to the enzyme concentration. The lower limit of the useful range is defined by the limit of detection (LOD) defining the lower limit of a reliable measurement with respect to the measurement noise occurring from autoxidation of the substrate hydrocoerulignone. The limit of blank (LOB) was determined from 48 measurements exchanging LPMO by buffer. The LOD was determined from 16 different NcLPMO9C concentrations, measured in four, fully randomized technical repeats. Assuming a Gaussian

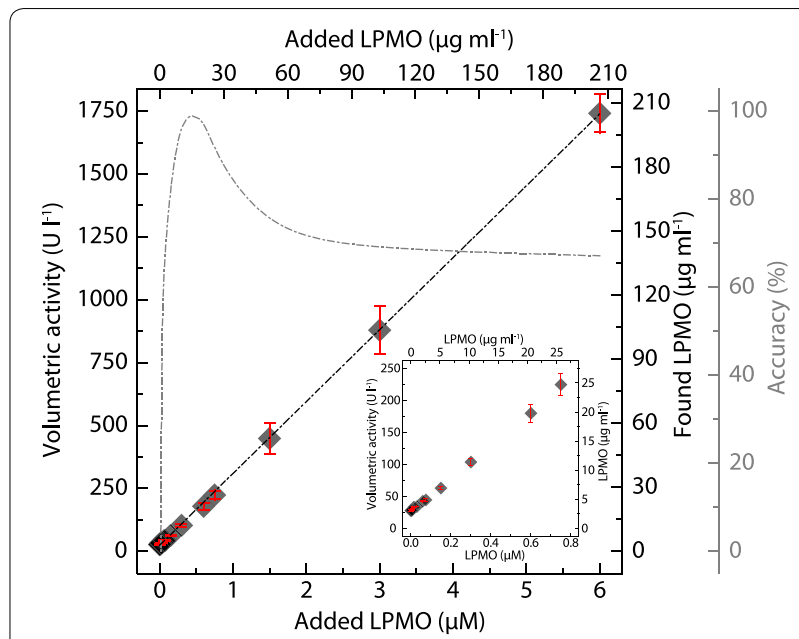

Fig. 4 Recovery study for different NCLPMO9C concentrations at $\mathrm{pH}$ 6.0. Dark gray diamonds represent the found NCLPMO9C concentration ( $Y$-axis) plotted against the added NCLPMO9C concentration ( $X$-axis). The activity was determined at $30^{\circ} \mathrm{C}$ using $500 \mu \mathrm{M}$ hydrocoerulignone and $100 \mu \mathrm{M} \mathrm{H}_{2} \mathrm{O}_{2}$ in $100 \mathrm{mM}$ sodium acetate buffer, $\mathrm{pH}$ 6.0. The found NCLPMO9C concentration was calculated from the measured volumetric activity using a specific activity of $138 \pm 12 \mathrm{U} \mathrm{g}^{-1}$ and the molecular mass of NCLPMO9C $\left(34,400 \mathrm{~g} \mathrm{~mol}^{-1}\right)$. Gray dashed dotted trace shows the concentration range of $\mathrm{NCLPMO9C}$ with the highest accuracy taking the standard deviation into account. The inset shows the low concentration range with the highest precision. All data are expressed as mean values $( \pm \mathrm{SD})$, from four independent repeats

distribution, 95\% represents the observed LOB values or LOD low concentration sample values that exceed the defined LOB, respectively. The remaining $5 \%$ of blank values are false positive, and only $5 \%$ of the low concentration samples will produce values below the LOB. When using $1.645 \times \mathrm{SD}$, no more than $5 \%$ of the values should be less than the LOB [20]. The LOD defines the lowest LPMO concentration that can be discriminated from the blank and was determined to be $0.015 \mu \mathrm{M}\left(0.52 \mu \mathrm{g} \mathrm{m} l^{-1}\right)$

Table 2 Specific activities of six different LPMOs from two different organisms

\begin{tabular}{|c|c|c|}
\hline & \multicolumn{2}{|c|}{ Specific activity $\left(\mathbf{U ~ g}^{-1}\right)$} \\
\hline & Hydrocoerulignone & 2,6-DMP \\
\hline \multicolumn{3}{|l|}{ Neurospora crassa } \\
\hline LPMO9C & $138 \pm 12$ & $31 \pm 3$ \\
\hline LPMO9E & $113 \pm 4$ & $22 \pm 3$ \\
\hline LPMO9J & $86 \pm 4$ & $13 \pm 1$ \\
\hline \multicolumn{3}{|c|}{ Crassicarpon hotsonii (syn. Myriococcum thermophilum) } \\
\hline LPMO (gene identifier) Myrth2p4_000359 & $120 \pm 5$ & $30 \pm 1$ \\
\hline LPMO (gene identifier) Myrth2p4_004260 & $137 \pm 4$ & $16 \pm 1$ \\
\hline LPMO (gene identifier) Myrth2p4_006403 & $110 \pm 2$ & $38 \pm 2$ \\
\hline
\end{tabular}

Measured under standard conditions with $500 \mu \mathrm{M}$ hydrocoerulignone (100 mM sodium acetate buffer, $\mathrm{pH} 6.0$ containing $100 \mu \mathrm{M} \mathrm{H}_{2} \mathrm{O}_{2}$ ) and 2,6-DMP (50 mM sodium phosphate buffer, $\mathrm{pH} 7.5$ containing $100 \mathrm{\mu M} \mathrm{H}_{2} \mathrm{O}_{2}$ ). Data expressed as mean values $( \pm \mathrm{SD})$, from three independent repeats 
of $\mathrm{NcLPMO} 9 \mathrm{C}$ at $\mathrm{pH}$ 6.0. When assuming that the average obtained specific LPMO activity of all measurements is $138 \mathrm{U} \mathrm{g}^{-1}$ and using the standard deviation of all individual measurements for the estimation, the LPMO concentration range with the highest accuracy can be determined. The highest accuracy, with the lowest standard deviation, is obtained for NcLPMO9C concentration of $0.2-1.2 \mu \mathrm{M}\left(6-40 \mu \mathrm{g} \mathrm{ml}^{-1}\right)$.

\section{Monitoring of NCLPMO9C expression}

To test the applicability of the LPMO activity assay for monitoring the recombinant expression of LPMO a $P$. pastoris fermentation according to Kittl et al. [21] was performed. We used the hydrocoerulignone assay as described in the protocol below (20 $\mu$ sample volume, $100 \mathrm{mM}$ sodium acetate buffer, $\mathrm{pH}$ 6.0) and the 2,6-DMP assay $(100 \mu \mathrm{l}$ sample volume, $50 \mu \mathrm{M}$ sodium phosphate buffer, $\mathrm{pH}$ 7.5) to determine the activity of expressed NcLPMO9C in the supernatant (Fig. 5). LPMO expression was induced with methanol and additional $\mathrm{CuSO}_{4}$ was added to a final concentration of $100 \mu \mathrm{M}$ to supplement copper for the active site of LPMO. Directly after the addition of copper a sample was taken to measure its effect on the assay. The presence of copper in the medium gave a negligible response of $1.9 \pm 0.6 \mathrm{U} \mathrm{l}^{-1}$ (Fig. 5). After induction (29 h after start of the batch phase), the

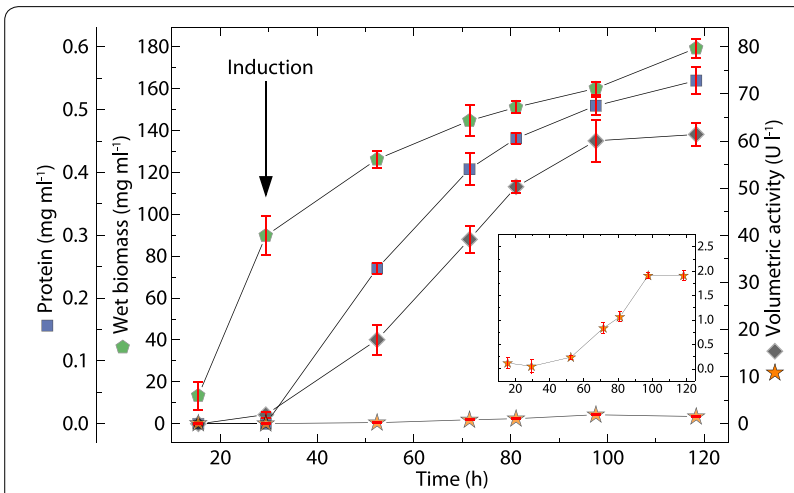

Fig. 5 Recombinant expression of NCLPMO9C using P. pastoris followed by the hydrocoerulignone assay. LPMO expression was induced after $29 \mathrm{~h}$ using methanol. The fermentation medium was supplemented with copper sulfate to reach a final concentration of $100 \mu \mathrm{M}$. A sample was immediately taken after copper addition to the medium to obtain a reference. Green pentagons show wet biomass, blue squares show extracellular protein concentration, black diamonds show activity measured with $500 \mu \mathrm{M}$ hydrocoerulignone as substrate (100 mM sodium acetate buffer, pH 6.0, $20 \mu$ l sample volume) and orange stars show activity with $1000 \mu \mathrm{M}$ 2,6-DMP (50 mM sodium phosphate buffer, $\mathrm{pH} 7.5,100 \mu \mathrm{l}$ sample volume). The activity of 2,6-DMP is magnified in the inset, which has the same units as the $X$-axis and the right $Y$-axis. All activity measurements were performed for $300 \mathrm{~s}$ at $30^{\circ} \mathrm{C}$ by the addition of $100 \mu \mathrm{M} \mathrm{H}_{2} \mathrm{O}_{2}$. All data are expressed as mean values $( \pm \mathrm{SD})$ from three independent measurements extracellular protein concentration increased over the next $90 \mathrm{~h}$ and so did the secreted NcLPMO9C activity. We measured LPMO activity directly from the centrifuged supernatant of the fermentation. The 2,6-DMP assay indicated a low, but measurable volumetric activity when using $100 \mu \mathrm{l}$ supernatant to increase the LPMO concentration in the assay. The hydrocoerulignone assay gave a much higher volumetric activity with only $20 \mu \mathrm{l}$ supernatant, which makes the hydrocoerulignone assay a much more sensitive alternative to the 2,6-DMP assay for monitoring the fermentation progress. The measurements showed nonlinearity between the used sample volumes and the determined enzymatic activities, with higher sample volumes resulting in proportionally lower volumetric activities. This was tested by adding purified NcLPMO9C to the fermentation media, which resulted in a $25 \%$ lower activity of LPMO measured by the hydrocoerulignone assay ( $\mathrm{pH}$ 6.0) and a 63\% lower activity of LPMO measured by the 2,6-DMP assay (pH 7.5), which indicated an influence of the sample matrix on the assay.

\section{Screening for inhibiting substances of the LPMO reaction}

Similar to the discovered effects of different buffer species, the matrix, e.g., the fermentation medium, can inhibit the reaction. Therefore, we screened for inhibitors that can compromise the detection of LPMO in a fermentation supernatant. For this screening both, the 2,6-DMP assay and the hydrocoerulignone assay were applied in a $100 \mathrm{mM}$ sodium acetate buffer, $\mathrm{pH}$ 6.0. Different media components such as yeast extract, yeast nitrogen base (YNB), casein peptone, and meat peptone, which are typically used in fermentation media were tested in two relevant concentrations ( 1 and $10 \mathrm{~g} \mathrm{l}^{-1} ; 9 \mathrm{~g} \mathrm{l}^{-1}$ for $\mathrm{YNB}$, Table 3). Under the same conditions, both assays are

Table 3 Effect of media components on NCLPMO9C activity

\begin{tabular}{|c|c|c|c|c|}
\hline \multirow[b]{3}{*}{ Concentration $\left(\mathrm{g}^{-1}\right)$} & \multicolumn{4}{|c|}{ Residual activity (\%) } \\
\hline & \multicolumn{2}{|c|}{ Hydrocoerulignone } & \multicolumn{2}{|l|}{ 2,6-DMP } \\
\hline & 1.0 & 10.0 & 1.0 & 10.0 \\
\hline Yeast nitrogen base $(\mathrm{YNB})^{\mathrm{a}}$ & $78.8 \pm 3.2$ & $29.0 \pm 3.9$ & $85.3 \pm 3.9$ & $40.1 \pm 3.7$ \\
\hline Meat peptone & $52.6 \pm 1.3$ & $23.2 \pm 1.5$ & $68.5 \pm 5.0$ & $10.9 \pm 2.4$ \\
\hline Casein peptone & $51.8 \pm 3.3$ & $12.8 \pm 1.0$ & $62.6 \pm 2.3$ & $15.6 \pm 1.9$ \\
\hline Yeast extract & $29.9 \pm 1.5$ & $13.8 \pm 1.5$ & $50.9 \pm 1.8$ & $4.4 \pm 0.8$ \\
\hline
\end{tabular}

Residual activities were calculated based on the concentration of added NCLPMO9C and its determined specific activity $\left(138 \mathrm{U} \mathrm{g}^{-1}\right.$ with hydrocoerulignone; $23 \mathrm{U} \mathrm{g}^{-1}$ 2,6-DMP). Assay conditions for hydrocoerulignone or 2,6-DMP respectively: 500 or $2000 \mu \mathrm{M}$ hydrocoerulignone or 2,6-DMP, 0.3 or $2.0 \mu \mathrm{M}$ NCLPMO9C, $100 \mu \mathrm{M} \mathrm{H}_{2} \mathrm{O}_{2}$ in $100 \mathrm{mM}$ sodium acetate buffer at $\mathrm{pH} 6.0$ and $30{ }^{\circ} \mathrm{C}$. The $\mathrm{pH}$ was measured before and after measurements. Data expressed as mean values $( \pm S D)$, from three independent repeats

a YNB $9 \mathrm{gl}^{-1}$ 
similarly affected, resulting in a decreased LPMO peroxidase activity with higher concentrations of the media component. The weakest inhibition was observed for YNB $\left(75 \%\right.$ residual activity at $\left.1 \mathrm{~g} \mathrm{l}^{-1}\right)$ and the strongest inhibition for yeast extract $(30-50 \%$ residual activity at $\left.1 \mathrm{~g} \mathrm{l}^{-1}\right)$. The addition of $10 \mathrm{~g} \mathrm{l}^{-1}$ yeast extract almost fully inhibits the LPMO activity in both assays.

To specify the media components inhibiting LPMO's peroxidase activity, specific components of these fermentation media were assayed: all 20 natural amino acids, different cations and anions, and carboxylic acids occurring in the fermentation supernatant or released by yeast or fungi during growth. Amino acids with a terminal carboxylic group on the side chain show a decrease in activity of at least $50 \%$, which is in correspondence with the trend that carboxylic groups inhibit the reaction (Table 4). As mentioned, NcLPMO9C shows negligible activity if histidine at $\mathrm{pH} 6.0$ is present. Also for cysteine no LPMO activity was observed. Aromatic amino acids show the strongest inhibition. Phenylalanine and tryptophan decrease the residual activity to 7 and 3\%, respectively, even at a lower concentration than other amino acids $(45 \mathrm{mM})$. Tyrosine, because of its even lower solubility was measured at a $2 \mathrm{mM}$ concentration,

Table 4 Effect of amino acids on NcLPMO9C activity

\begin{tabular}{lrr}
\hline & \multicolumn{2}{c}{ Residual activity (\%) } \\
\cline { 2 - 3 } & Hydrocoerulignone & 2,6-DMP \\
\hline Arg (R) & $43.9 \pm 0.7$ & $34.0 \pm 3.1$ \\
His (H) & $0.3 \pm 0.3$ & $0.1 \pm 0.1$ \\
Lys (K) & $53.5 \pm 2.7$ & $36.0 \pm 3.7$ \\
Asp (D) & $39.9 \pm 3.3$ & $50.8 \pm 1.5$ \\
Glu (E) & $57.4 \pm 2.0$ & $46.5 \pm 4.8$ \\
Ser (S) & $19.1 \pm 0.9$ & $34.6 \pm 1.2$ \\
Thr (T) & $13.0 \pm 0.5$ & $18.5 \pm 1.6$ \\
Asn (N) & $10.8 \pm 0.4$ & $10.6 \pm 0.7$ \\
Gln (Q) & $25.2 \pm 0.9$ & $35.9 \pm 1.6$ \\
Cys (C) & $3.7 \pm 0.2$ & $0.1 \pm 0.1$ \\
Gly (G) & $49.1 \pm 1.2$ & $44.0 \pm 3.4$ \\
Pro (P) & $48.5 \pm 1.6$ & $37.1 \pm 1.1$ \\
Ala (A) & $39.9 \pm 1.7$ & $62.5 \pm 0.3$ \\
Val (V) & $23.3 \pm 2.3$ & $42.4 \pm 2.2$ \\
Ile (I) & $35.5 \pm 0.9$ & $47.9 \pm 3.2$ \\
Leu (L) & $38.6 \pm 1.1$ & $49.1 \pm 0.8$ \\
Met (M) & $12.0 \pm 0.6$ & $21.7 \pm 1.7$ \\
Phe (F) & $7.5 \pm 0.4$ & $14.9 \pm 0.1$ \\
Tyr (Y) & $81.5 \pm 3.6$ & $91.8 \pm 8.3$ \\
Trp (W) & $3.5 \pm 0.4$ & $16.2 \pm 2.3$ \\
\hline Assaysand & &
\end{tabular}

Assays and calculations were performed as indicated in Table 2. Data expressed as mean values $( \pm S D)$, from three independent repeats

${ }^{a}$ Asp (D), Glu (E), Trp (W) 45 mM; Tyr (Y) 2 mM which shows still an inhibition of about 10\%. Salts/ions have very little or no effect on the LPMO activity except sulfate, which decreases NcLPMO9C activity to 30-39\% residual activity (Table 5). This can be interpreted as interaction between the oxyanion and the copper center as already found for phosphate buffers. A strong inhibitory effect was observed for carboxylic acids, especially oxalic acid (Table 6). The bidentate property of oxalic acid could be the reason for the strong inhibitory effect.

\section{General application rules for the assay}

The obtained data were used to optimize the LPMO hydrocoerulignone assay in regard to specificity, accuracy, sensitivity, and robustness to improve its applicability in different matrices. General factors influencing the LPMO peroxidase activity in the hydrocoerulignone assay are shown in Fig. 6. Four factors have to be adjusted to increase the sensitivity and robustness of the assay: (1) Denticity of the buffer species. LPMO activity can be compromised by bi- and tridendate anions. Carboxylic acid groups and the oxy-groups of phosphate and sulfate oxyanions show an inhibitory effect. The monocarboxylic acetate ion compromises LPMO activity very little. (2) Increasing the ionic strength of a buffer generally reduces LPMO activity, and this is observed even for an acetate buffer. (3) A higher $\mathrm{pH}$ increases LPMO's peroxidase activity exponentially, which can be used to measure very low LPMO concentrations at $\mathrm{pH} 7-8$, which enhances the enzymatic activity. (4) An increased concentration of the chromogenic substrate hydrocoerulignone and cosubstrate $\mathrm{H}_{2} \mathrm{O}_{2}$ increases the activity. However, the limits for using very high concentrations is an increased, nonenzymatic autoxidation of hydrocoerulignone at concentrations above $500 \mu \mathrm{M}$ and an increased deactivation of LPMO activity at $\mathrm{H}_{2} \mathrm{O}_{2}$ concentrations above $100 \mu \mathrm{M}$.

Table 5 Effect of salts on NcLPMO9C activity

\begin{tabular}{llc}
\hline & \multicolumn{2}{l}{ Residual activity (\%) } \\
\cline { 2 - 3 } & Hydrocoerulignone & 2,6-DMP \\
\hline $\mathrm{NaF}$ & $65.9 \pm 10.0$ & $74.0 \pm 2.1$ \\
$\mathrm{NaCl}$ & $105.0 \pm 2.6$ & $92.9 \pm 0.6$ \\
$\mathrm{KCl}$ & $80.4 \pm 0.8$ & $91.6 \pm 2.8$ \\
$\mathrm{MgCl}_{2}$ & $94.8 \pm 5.7$ & $103.5 \pm 2.8$ \\
$\mathrm{CaCl}_{2}$ & $84.0 \pm 1.4$ & $107.2 \pm 2.3$ \\
$\mathrm{Nal}$ & $n . m$. & $86.7 \pm 25.3$ \\
$\mathrm{KBr}$ & $84.5 \pm 5.5$ & $84.5 \pm 6.2$ \\
$\mathrm{NaNO}_{3}$ & $82.8 \pm 1.2$ & $97.2 \pm 2.7$ \\
$\mathrm{Na}_{2} \mathrm{SO}_{4}$ & $30.2 \pm 4.5$ & $38.8 \pm 3.4$ \\
\hline $\mathrm{Assays}$ &
\end{tabular}

Assays and calculations were performed as indicated in Table 2. Data expressed as mean values $( \pm S D)$, from three independent repeats

n.m. not measured; strong influences on assay 
Table 6 Effect of carboxylic acids on NcLPMO9C activity

\begin{tabular}{|c|c|c|c|c|c|c|}
\hline \multirow[b]{3}{*}{ Concentration (mM) } & \multicolumn{6}{|c|}{ Specific activity $\left(\mathrm{U} \mathrm{g}^{-1}\right)$} \\
\hline & \multicolumn{3}{|c|}{ Hydrocoerulignone } & \multicolumn{3}{|l|}{ 2,6-DMP } \\
\hline & 30 & 100 & 300 & 30 & 100 & 300 \\
\hline Formic acid & $243 \pm 15$ & $186 \pm 4$ & $175 \pm 15$ & $36 \pm 1$ & $31.3 \pm 0.3$ & $17 \pm 1$ \\
\hline Acetic acid & $226 \pm 17$ & $138 \pm 12$ & $69 \pm 10$ & $33 \pm 2$ & $23 \pm 1$ & $13 \pm 1$ \\
\hline Oxalic acid & $4 \pm 1$ & $2 \pm 1$ & $0.4 \pm 0.3$ & $0.8 \pm 0.2$ & $0.2 \pm 0.1$ & $0.1 \pm 0.1$ \\
\hline Malonic acid & $24 \pm 2$ & $9 \pm 1$ & $3 \pm 1$ & $3.6 \pm 0.1$ & $0.7 \pm 0.1$ & $0.1 \pm 0.1$ \\
\hline Succinic acid & $84 \pm 3$ & n.m. & n.m. & $15.3 \pm 0.4$ & $11.8 \pm 0.1$ & $10 \pm 1$ \\
\hline Malic acid & $66 \pm 7$ & $28 \pm 5$ & $12 \pm 2$ & $12.6 \pm 0.1$ & $5.4 \pm 0.2$ & $2.1 \pm 0.1$ \\
\hline Tartaric acid & $106 \pm 5$ & $46 \pm 3$ & $19.0 \pm 0.4$ & $18 \pm 1$ & $9 \pm 1$ & $3.5 \pm 0.3$ \\
\hline Maleic acid & $55 \pm 4$ & $6 \pm 3$ & $0.2 \pm 0.1$ & $9.8 \pm 0.1$ & $4.6 \pm 0.1$ & $2.9 \pm 0.2$ \\
\hline Citric acid & $11 \pm 1$ & $4 \pm 1$ & $0.3 \pm 0.2$ & $1.7 \pm 0.1$ & $0.5 \pm 0.1$ & $0.2 \pm 0.1$ \\
\hline
\end{tabular}

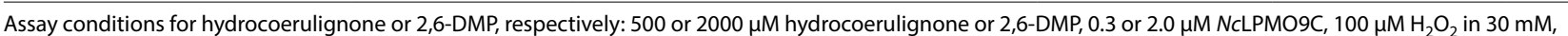
$100 \mathrm{mM}$ and $300 \mathrm{mM}$ sodium carboxylate buffers at $\mathrm{pH} 6.0$ and $30^{\circ} \mathrm{C}$. The pH was measured before and after measurements. Data expressed as mean values ( $\pm \mathrm{SD}$ ), of four independent repeats

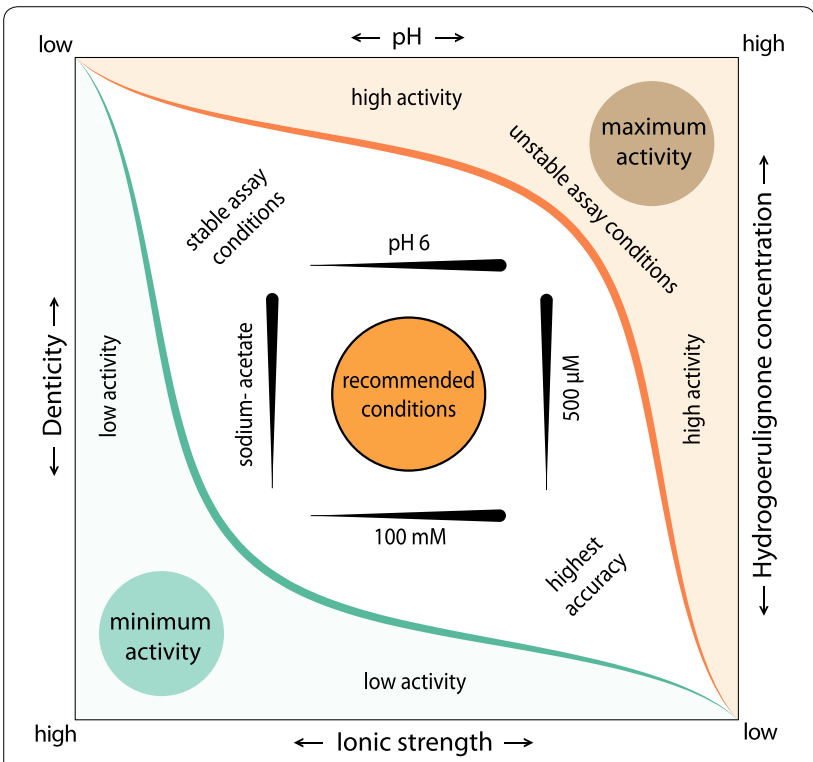

Fig. 6 Schematic guideline for the activity assay. Based on all data collected, four major factors were identified to adjust the assay: ionic strength of the buffer, buffer ion denticity, buffer $\mathrm{pH}$ and substrate concentration. The green and orange areas correspond to the region lowest and highest LPMO activity, respectively. Black arrows indicate the increase or decrease in activity by adjusting a factor. As a good starting point for the assay, we recommend $100 \mathrm{mM}$ sodium acetate, $\mathrm{pH}$ 6.0, $500 \mu \mathrm{M}$ hydrocoerulignone as chromogenic substrate and $100 \mu \mathrm{M}$ hydrogen peroxide as cosubstrate. The area around the recommended conditions indicates conditions in which LPMO activity can be detected, but is not optimized for maximum reliability This region can be used to characterize the LPMO's behavior under different conditions, e.g., for a $\mathrm{pH}$ profile. The area around the recommended conditions indicates conditions in which LPMO activity can be detected, but is not optimized for maximum reliability. This region can be used to characterize the LPMO's behavior under different conditions, e.g., for a pH profile. We suggest to start with small changes to our recommended conditions to not end up in the green or orange region, where either no activity can be detected or the activity is too high and autoxidation inactivates LPMO too fast
The developed assay protocol is a compromise between a non-inhibiting buffer at a close to physiological $\mathrm{pH}$ value, and substrate and cosubstrate concentrations providing a good sensitivity without having to consider blank reactions or enzyme deactivation during the assay. However, when using proper controls and a short assay time, the sensitivity of the assay can be boosted by a factor 10-100 using a higher $\mathrm{pH}$, higher hydrocoerulignone and higher $\mathrm{H}_{2} \mathrm{O}_{2}$ concentrations according to Fig. 2 and Table 1. Our recommendation in the following assay protocol is a good starting point for testing LPMO activity, however, we note that other LPMOs can differ from NcLPMO9C and that the assay Factors 1-4 should therefore be considered for each enzyme. In case of multiple measurements required at the same time, the adaptation of the cuvette-based assay to microtiter plates is possible by adjusting the sample and reagent volumes accordingly. However, the shorter and less defined optical pathlength will result in a higher limit of detection and lower sensitivity.

\section{Discussion}

The molar absorption coefficient of coerulignone at $469 \mathrm{~nm}$ has been determined to be $53,200 \mathrm{M}^{-1} \mathrm{~cm}^{-1}$. This high value allows low amounts of produced coerulignone to be detected and ensures a high sensitivity of the assay. The increased activity is not the result of a $\mathrm{pH}$-induced change in the molar absorption coefficient of the chromogenic product coerulignone [7]. The reason to bypass 2,6-DMP in the assay is the faster reaction rate of LPMO with hydrocoerulignone at the physiologically relevant $\mathrm{pH}$ around and below $\mathrm{pH} 6$ [10]. The faster reaction rate results from a better binding to the active site of LPMO which is demonstrated by a lower apparent $K_{\mathrm{M}}$ value for 
hydrocoerulignone than for 2,6-DMP, but also from a more favorable, lower oxidation potential of hydrocoerulignone. When comparing the difference in the oxidative onset potentials, the $160 \mathrm{mV}$ lower potential of hydrocoerulignone can be recalculated to a $\sim 30 \mathrm{~kJ} \mathrm{~mol}^{-1}$ reduction of the Gibbs free energy necessary to overcome the activation energy barrier. Hydrocoerulignone as substrate for LPMO has a very similar behavior when compared to the $\mathrm{pH}$ profile published for 2,6-DMP. No major differences are observed. For comparison of both datasets, it has to be noted that $\mathrm{pH}$-dependent activity measurements were using a $1 \mathrm{mM}$ hydrocoerulignone concentration, whereas $25 \mathrm{mM}$ 2,6-DMP was used. The higher 2,6-DMP concentration was necessary to counterbalance the lower activity of LPMO for 2,6-DMP and to speed up the assay. For hydrocoerulignone as substrate, a much lower concentration suffices to obtain an equal specific activity in the assays. The previously published LPMO activity assay based on 2,6-DMP has a LOD of $0.0125 \mu \mathrm{M}\left(0.43 \mu \mathrm{g} \mathrm{ml}^{-1}\right)$ NcLPMO9C at pH 7.5 [7]. By using hydrocoerulignone, almost the same LOD $\left(0.015 \mu \mathrm{M}, 0.52 \mu \mathrm{g} \mathrm{ml}^{-1}\right)$ can be achieved, however, under the physiologic $\mathrm{pH}$ of 6.0, which results for both assays in 50 times lower LOD as for the Amplex red assay [21]. Under steady-state conditions, a direct comparison of the standard assays with hydrocoerulignone and 2,6-DMP showed higher turnover stability for LPMO. One reason is the two times lower $\mathrm{H}_{2} \mathrm{O}_{2}$ turnover of LPMO necessary to convert hydrocoerulignone to coerulignone compared to starting from 2,6-DMP, the other possible reason a lack in 2,6-DMP radical formation. The higher turnover stability and higher rate for LPMO using hydrocoerulignone are advantageous to monitor LPMO activity during fermentations. We could show that by using the hydrocoerulignone assay, the increase in LPMO activity could be correlated with the increase in wet biomass and extracellular protein concentration. However, we recognized lower volumetric activities of purified NcLPMO9C in the fermentation medium, which was confirmed by testing different common media components. Furthermore, several amino acids and carboxylic acids highly inhibit LPMO activity in the assays. Histidine, cysteine, and oxalic acid completely quench the signal. We tested cysteine, which is already known as reductant for LPMO $[22,23]$ as reductant for coerulignone (data not shown) and conclude that cysteine is, on the one hand, reacting with LPMO and also quickly reducing the final product of the assay. Therefore, LPMO activity cannot be measured in presence of higher cysteine concentrations. For histidine and oxalic acid, a chelating effect is the most obvious conclusion. The bidentate molecule oxalate most potently inhibits the active site of LPMO, possibly through an optimal bidentate binding to the copper. As a general trend, we can conclude that higher denticity and higher ionic strength decreases the LPMO activity in the assay. These kinds of buffer species should be avoided when performing the LPMO activity assays using hydrocoerulignone or 2,6-DMP.

\section{Conclusions}

The hydrocoerulignone-based LPMO activity assay is a fast and easy method to follow recombinant LPMO production and enzyme purification as well as to study enzyme deactivation or substrate binding. When using hydrocoerulignone, LPMO activity can be measured under physiologically relevant, acidic $\mathrm{pH}$ conditions, which is an advantage over the 2,6-DMP assay. The lower necessary sample volume reduces the influence of inhibitory matrix compounds and improves the monitoring of LPMO activity during recombinant production and purification. Due to its sensitivity, less protein can be used in biochemical characterization. The inhibition of the assayed LPMO activity by various substances might be a good starting point for further studies on LPMO inhibitors.

\section{Materials and methods}

\section{Materials and enzymes}

All chemicals were of the highest purity grade available and were purchased from Sigma-Aldrich unless stated otherwise. Methanol was purchased from Merck, hydrocoerulignone [3, $3^{\prime}, 5,5^{\prime}$-tetramethoxy $\left(1,1^{\prime}\right.$ biphenyl)-4,4'-diol; National Center for Biotechnology Information. PubChem Database. CID $=256604$, https://pubchem.ncbi.nlm.nih.gov/compound/256604 (Accessed on 16 Sept. 2019)] from MP Biomedicals (CA, US). Lytic polysaccharide monooxygenases (NcLPMO9C, sequence Accession number EAA36362.1; NcLPMO9E, sequence Accession number EAA26873.1; NcLPMO9J, sequence Accession number CAE81966.1; ChLPMO gene identifier Myrth2p4_000359, Myrth2p4_004260, Myrth2p4_006403) from Neurospora crassa and Crassicarpon hotsonii (syn: Myriococcum thermophilum) were recombinantly expressed in Pichia pastoris X-33 according to Kittl et al. [21]. The production in a 5-L bioreactor and chromatographic purification were also performed according to this publication. The purity was verified by SDS-PAGE.

\section{Measurement of LPMO, protein, and hydrogen peroxide concentration}

The concentration of purified LPMO was determined in a 3-mm quartz cuvette from its UV-Vis absorption at $280 \mathrm{~nm}$ using the calculated molar absorption coefficient and the molecular mass of NcLPMO9C: 
$\varepsilon_{280}=46,910 \quad \mathrm{M}^{-1} \quad \mathrm{~cm}^{-1}, \quad 34,300 \quad \mathrm{~g}^{-1} \mathrm{~mol}^{-1} ; \quad N c \mathrm{LP}-$ MO9E: $\quad \varepsilon_{280}=42,370 \quad \mathrm{M}^{-1} \mathrm{~cm}^{-1}, 30,876 \mathrm{~g} \mathrm{~mol}^{-1}$; NcLPMO9J: $\varepsilon_{280}=47,870 \mathrm{M}^{-1} \mathrm{~cm}^{-1} ; 32,673 \mathrm{~g} \mathrm{~mol}^{-1}$; ChLPMO (gene identifier) Myrth2p4_000358: $\varepsilon_{280}=44,140 \quad \mathrm{M}^{-1} \quad \mathrm{~cm}^{-1}, \quad 22,515 \quad \mathrm{~g} \quad \mathrm{~mol}^{-1}$; ChLPMO (gene identifier) Myrth2p4_004260: $\varepsilon_{280}=45,880 \mathrm{M}^{-1} \mathrm{~cm}^{-1}, 29,776 \mathrm{~g} \mathrm{~mol}^{-1}$; ChLPMO (gene identifier) Myrth2p4_006403: $\varepsilon_{280}=39,670 \mathrm{M}^{-1} \mathrm{~cm}^{-1}$, $32,971 \mathrm{~g} \mathrm{~mol}^{-1}$. The protein concentration in fermentation samples was measured by the method of Bradford using bovine serum albumin for the standard curve [24]. The concentration of $\mathrm{H}_{2} \mathrm{O}_{2}$ in stock solutions was determined in a $10-\mathrm{mm}$ quartz cuvette from the UV-Vis absorption at $240 \mathrm{~nm}$ using its molar absorption coefficient of $\varepsilon_{240}=43.6 \mathrm{M}^{-1} \mathrm{~cm}^{-1}$.

\section{Hydrocoerulignone stock solution and molar absorption coefficient}

Water, isopropanol, acetonitrile, and DMSO were tested to dissolve hydrocoerulignone from which DMSO showed the best dissolving properties and was selected to prepare the hydrocoerulignone stock solution. To that purpose, hydrocoerulignone was dissolved for $1 \mathrm{~h}$ in pure DMSO in a sample rotator. Before further usage the solution was centrifuged to remove minor particles from the supernatant. By measuring the absorbance of various hydrocoerulignone concentrations at pH 6.0 in $50 \mathrm{mM}$ sodium phosphate buffer (remaining DMSO concentration $2 \%$ ) between 5 and $80 \mu \mathrm{M}$ the molar absorption coefficient at $280 \mathrm{~nm}\left(\varepsilon_{280}\right.$, hydrocoerulignone $=16,260 \mathrm{M}^{-1} \mathrm{~cm}^{-1}$ ) was calculated by linear regression (Additional file 1).

\section{LPMO activity assay}

The suggested standard conditions for the LPMO activity assay using hydrocoerulignone are $30{ }^{\circ} \mathrm{C}, 100 \mu \mathrm{M}$ $\mathrm{H}_{2} \mathrm{O}_{2}, 500 \mu \mathrm{M}$ hydrocoerulignone, $100 \mathrm{mM}$ sodium acetate buffer at $\mathrm{pH} 6.0$ for maximum robustness, sensitivity under physiological conditions and a reaction time of $300 \mathrm{~s}$. For blank reactions, same conditions have to be performed without additions of LPMO and the resulting rate has to be subtracted from the rate with additions of LPMO. One unit of LPMO activity is defined as the conversion of $1 \mu \mathrm{mol}$ hydrocoerulignone or the formation of $1 \mu \mathrm{mol}$ coerulignone per min under reaction conditions. The specific activity can be calculated from the slope of the steady-state rate by using the molar absorption coefficient of coerulignone $\left(\varepsilon_{469}=53,200 \mathrm{M}^{-1} \mathrm{~cm}^{-1}\right)$ and the LPMO concentration. For inhibition tests, the $100 \mathrm{mM}$ sodium acetate buffer at $\mathrm{pH} 6.0$ was supplemented with different compounds and the $\mathrm{pH}$ measured before and after the measurements.

\section{LPMO activity assay protocol}

Based on the obtained data, we recommend the following basic assay protocol to test the peroxidase activity of LPMO:

Step 1: Prepare a $106 \mathrm{mM}$ sodium acetate buffer, $\mathrm{pH}$ 6.0. The final concentration of the buffer in the cuvette will be $100 \mathrm{mM}$. Also prepare a $25 \mathrm{mM}$ hydrocoerulignone stock solution in pure DMSO and a $5 \mathrm{mM} \mathrm{H}_{2} \mathrm{O}_{2}$ stock solution in highly pure water. The solutions should not be mixed before the addition to the cuvette and should be used within $12 \mathrm{~h}$.

Step 2: Take $1 \mathrm{ml}$ of sample from the culture supernatant and centrifuge for $3 \mathrm{~min}$ at $6000 \times g$ to remove cells and other solids. Carefully remove $500 \mu \mathrm{l}$ of the clear supernatant from the sediment and transfer to a clean vial. If taken from a clear solution, the sample needs no centrifugation and a smaller volume suffices. Store the sample on ice until use.

Step 3: Transfer $940 \mu$ lof buffer, $20 \mu$ of the hydrocoerulignone stock solution and $20 \mu \mathrm{l}$ of the $\mathrm{H}_{2} \mathrm{O}_{2}$ stock solution into a cuvette and incubate the cuvette for $15 \mathrm{~min}$ at $30{ }^{\circ} \mathrm{C}$ before continuing with Step $4 \mathrm{a}$ and $4 \mathrm{~b}$. Due to the autoxidation of hydrocoerulignone a blank reaction should be measured without adding LPMO.

Step 4a (Reference experiment): Add $20 \mu \mathrm{l}$ of sodium acetate buffer, pH 6.0 (also used if a dilution of the LPMO sample is done) or a fermentation sample without LPMO and measure the slope of the blank reaction.

Step 4b (Enzyme assay): Add $20 \mu \mathrm{l}$ of properly diluted LPMO and measure the slope of the LPMO catalyzed oxidation of hydrocoerulignone. If the LPMO activity is low, a higher sample volume can be used, but the buffer volume and ionic strength have to be adapted accordingly. The increase in absorbance at $469 \mathrm{~nm}$ is measured for $300 \mathrm{~s}$ at $30{ }^{\circ} \mathrm{C}$ and if the blank reaction shows a significant rate, it is subtracted.

Finally, the volumetric LPMO peroxidase activity is calculated from Eq. 4 by using the correct enzyme factor (EF, Eq. 5), which is based on the sample volume, the enzyme dilution, and the molar absorption coefficient of coerulignone $\left(\varepsilon_{469}=53.2 \mathrm{mM}^{-1} \mathrm{~cm}^{-1}\right)$.

$$
\text { volumetric activity }\left(\mathrm{UL}^{-1}\right)=\operatorname{rate}\left(\min ^{-1}\right) \times \mathrm{EF}
$$




$$
\mathrm{EF}=\frac{\text { total volume }(\mathrm{ml}) \times \text { dilution factor }}{\text { sample volume }(\mathrm{ml}) \times \text { pathlength }(\mathrm{cm}) \times \text { molar absorption coefficient }\left(\mathrm{mM}^{-1} \mathrm{~cm}^{-1}\right)}
$$

\section{$\mathrm{pH}$ profile of LPMO activity}

NcLPMO9C was used to measure enzymatic activity with final concentrations of $100 \mathrm{mM}$ buffer, $100 \mu \mathrm{M} \mathrm{H}_{2} \mathrm{O}_{2}$, $1000 \mu \mathrm{M}$ hydrocoerulignone, and $0.3 \mu \mathrm{M}$ NcLPMO9C. Anionic buffers were titrated with sodium hydroxide and the cationic buffers with hydrochloric acid. All measurements were performed at $30^{\circ} \mathrm{C}$ and the change in absorbance at $469 \mathrm{~nm}$ was followed in a PerkinElmer Lambda $35 \mathrm{UV} / \mathrm{Vis}$ spectrophotometer in quadruplets. Blank reactions were performed for all buffers and $\mathrm{pH}$ values to obtain only the LPMO activity.

\section{Determination of kinetic constants and substrate concentration}

Kinetic constants of LPMO were determined in $50 \mathrm{mM}$ sodium phosphate buffer, pH 6.0 using a $0.3 \mu \mathrm{M} \mathrm{NcLP-}$ MO9C concentration. All experiments were performed in quadruplets and blank reaction rates were subtracted. The resulting curves were fitted to the Michaelis-Menten equation by nonlinear least-square regression using SigmaPlot 12.5 (Systat Software, Chicago, Illinois, USA).

\section{Cyclic voltammetry}

Measurements were performed at $25{ }^{\circ} \mathrm{C}$ in a $15-\mathrm{ml}$ electrochemical cell. The system setup involved a rotating disk electrode made from a glassy carbon working electrodes ( $3 \mathrm{~mm}$ in diameter, $\mathrm{BASi}$ ), an $\mathrm{Ag} \mid \mathrm{AgCl}$ (3 M $\mathrm{KCl})$ reference electrode, a platinum counter electrode, an Autolab Rotator (RDE80739), an Autolab controller and an Autolab potentiostat (PBSTAT204). The system was controlled using the NOVA 1.11 program from Autolab. Before measurements, the glassy carbon disc electrode was polished with an aluminum oxide suspension (Buehler; Master Prep Polishing Suspension, $0.05 \mu \mathrm{m}$ ) before each measurement. The rotating disc electrode was set to $250 \mathrm{rpm}$ before starting the cyclic voltammetry measurement by sweeping between -150 and $400 \mathrm{mV}$ vs. the reference electrode with scan rate of $3 \mathrm{mV} \mathrm{s}^{-1}$. For all measurements a $50 \mathrm{mM}$ sodium phosphate buffer was added to the cell. The buffer was left to equilibrate the system for 5 min before hydrocoerulignone was added and mixed for 5 min more to equilibrate before starting the measurement.

\section{Limit of detection}

The limit of detection (LOD) for the LPMO assay with hydrocoerulignone was measured according to Armbruster and Pry [20]. Forty-eight blank reactions without LPMO were measured to calculate the limit of blank (LOB). For the LOD measurement, two independent LPMO dilution series were prepared and measured in a completely randomized measurement scheme, which was prepared by using the RAND function in Microsoft Excel 2016 (Microsoft Cooperation, Redmond, WA, USA). Quadruplets were measured to calculate the specific activity. To recalculate the NcLPMO9C concentration and to determine the accuracy, which represents the range of NcLPMO9C concentrations with the lowest standard deviation compared with all measurements, the average activity of the most accurate (within $\sim 80 \%$ ) were used.

\section{Supplementary information}

\section{Supplementary information accompanies this paper at https://doi. org/10.1186/s13068-019-1624-3.}

Additional file 1. Absorbance of different hydrocoerulignone concentrations at $280 \mathrm{~nm}$ for the calculation of the molar absorbance coefficient $\left(\varepsilon_{280}=16,260 \mathrm{M}^{-1} \mathrm{~cm}^{-1}\right.$ ). LibreOffice_v.6 (Berlin, Germany) was used for a linear regression fit, the calculation of the slope and intercept. Measured in $50 \mathrm{mM}$ sodium phosphate buffer at $\mathrm{pH} 6.0$.

Additional file 2. (a) Steady-state kinetic measurements of hydrogen peroxide with $500 \mu \mathrm{M}$ hydrocoerulignone and (b) of hydrocoerulignone with $100 \mu \mathrm{M} \mathrm{H}_{2} \mathrm{O}_{2}$. No saturation was achieved for hydrocoerulignone and therefore the kinetic constants for $\mathrm{H}_{2} \mathrm{O}_{2}$ were determined under apparent, non-pseudo-first-order conditions.

Additional file 3. Ratio of blank reactions and reaction rates with LPMO of different hydrocoerulignone and $\mathrm{H}_{2} \mathrm{O}_{2}$ concentrations. Grey area, blank reaction lower than $20 \%$ of total reaction rate. Measured in $50 \mathrm{mM}$ sodium phosphate buffer at $\mathrm{pH} 6.0$ with NCLPMO9c at $30^{\circ} \mathrm{C}$.

\section{Abbreviations}

2,6-DMP: 2,6-dimethoxyphenol; hydrocoerulignone:

3,3',5,5'-tetramethoxy (1,1'-biphenyl)-4,4'-diol; coerulignone:

3,3',5,5'-tetramethoxy-4,4'-diphenoquinone; DMSO: dimethylsulfoxide; GMC: glucose-methanol-choline; $\mathrm{H}_{2} \mathrm{O}_{2}$ : hydrogen peroxide; LOB: limit of blank; LOD: limit of detection; LPMO: lytic polysaccharide monooxygenase; SD: standard deviation; YNB: yeast nitrogen base.

\section{Acknowledgements}

The authors thank D. Kracher for valuable discussions and input and P. Cannazza for help during enzyme production.

\section{Authors' contributions}

$\mathrm{EB}$ and $\mathrm{RL}$ developed the enzyme assay and planned experiments. SD performed kinetic and $\mathrm{pH}$ profile measurements. EB and AP performed inhibition experiments. $\mathrm{HC}$ performed electrochemical measurements. EB, TR, CO, and $\mathrm{RL}$ analyzed experimental data. EB drafted the manuscript. $\mathrm{CO}$ and $\mathrm{RL}$ initiated and coordinated the study. EB, TR, CO, and RL wrote the final version of the manuscript. All authors read and approved the final manuscript.

\section{Funding}

This work was supported by the Austrian Science Fund project (FWF 12385-N28), the doctoral program "BioTop-Biomolecular Technology of 
Proteins" (FWF W1224), the Erasmus + program which provided a scholarship to AP, and the WTZ project HR 14/2018 from OeAD and BMBWF granted to RL.

\section{Availability of data and materials}

The datasets used and/or analyzed during the current study are available from the corresponding author on reasonable request.

\section{Ethics approval and consent to participate}

Not applicable.

\section{Consent for publication}

All authors have seen and approved the manuscript before submission to Biotechnology for Biofuels.

\section{Competing interests}

The authors declare that they have no competing interests.

\section{Author details}

1 Biocatalysis and Biosensor Laboratory, Department of Food Science and Technology, BOKU-University of Natural Resources and Life Sciences, Muthgasse 18, 1190 Vienna, Austria. ${ }^{2}$ Institute of Molecular Modeling and Simulation, BOKU-University of Natural Resources and Life Sciences, Muthgasse 18, 1190 Vienna, Austria. ${ }^{3}$ Department of Biochemical Engineering, Faculty of Food Technology and Biotechnology, University of Zagreb, Pierottijeva 6, 10000 Zagreb, Croatia.

Received: 24 September 2019 Accepted: 28 November 2019 Published online: 05 December 2019

\section{References}

1. Couturier M, et al. Lytic xylan oxidases from wood-decay fungi unlock biomass degradation. Nat Chem Biol. 2018;14(3):306-10. https://doi. org/10.1038/nchembio.2558.

2. Filiatrault-Chastel C, et al. AA16, a new lytic polysaccharide monooxygenase family identified in fungal secretomes. Biotechnol Biofuels. 2019;12(1):55. https://doi.org/10.1186/s13068-019-1394-y.

3. Levasseur A, et al. Expansion of the enzymatic repertoire of the CAZy database to integrate auxiliary redox enzymes. Biotechnol Biofuels. 2013;6(1):1-14. https://doi.org/10.1186/1754-6834-6-41.

4. Sabbadin F, et al. An ancient family of lytic polysaccharide monooxygenases with roles in arthropod development and biomass digestion. Nat Commun. 2018;9(1):756. https://doi.org/10.1038/s41467-018-03142-x.

5. Chylenski $P$, et al. Lytic polysaccharide monooxygenases in enzymatic processing of lignocellulosic biomass. ACS Catal. 2019;9(6):4970-91. https ://doi.org/10.1021/acscatal.9b00246

6. Bissaro B, et al. Oxidative cleavage of polysaccharides by monocopper enzymes depends on H2O2. Nat Chem Biol. 2017;13(10):1123-8. https:// doi.org/10.1038/nchembio.2470.

7. Breslmayr E, et al. A fast and sensitive activity assay for lytic polysaccharide monooxygenase. Biotechnol Biofuels. 2018;11(1):79. https://doi. org/10.1186/s13068-018-1063-6.

8. Cannella D, et al. Light-driven oxidation of polysaccharides by photosynthetic pigments and a metalloenzyme. Nat Commun. 2016;7(1):11134 https://doi.org/10.1038/ncomms11134.

9. Frommhagen $\mathrm{M}$, et al. Boosting LPMO-driven lignocellulose degradation by polyphenol oxidase-activated lignin building blocks. Biotechnol Biofuels. 2017;10(1):1-16. https://doi.org/10.1186/s13068-017-0810-4.

10. Kracher $D$, et al. Extracellular electron transfer systems fuel cellulose oxidative degradation. Science. 2016;352(6289):1098-101. https://doi. org/10.1126/science.aaf3165.

11. Garajova S, et al. Single-domain flavoenzymes trigger lytic polysaccharide monooxygenases for oxidative degradation of cellulose. Sci Rep. 2016;6:1-9. https://doi.org/10.1038/srep28276.

12. Hegnar $\mathrm{OA}$, et al. pH-dependent relationship between catalytic activity and hydrogen peroxide production shown via characterization of a lytic polysaccharide monooxygenase from Gloeophyllum trabeum. Appl Environ Microbiol. 2019;85(5):e02612-8. https://doi.org/10.1128/aem.02612 -18 .
13. de Gouvêa PF, et al. Lytic polysaccharide monooxygenase from Aspergillus fumigatus can improve enzymatic cocktail activity during sugarcane bagasse hydrolysis. Protein Pept Lett. 2019;26(5):377-85. https://doi. org/10.2174/0929866526666190228163629.

14. Koskela S, et al. Lytic polysaccharide monooxygenase (LPMO) mediated production of ultra-fine cellulose nanofibres from delignified softwood fibres. Green Chem. 2019. https://doi.org/10.1039/c9gc02808k.

15. Semenova MV, et al. Purification and characterization of two forms of the homologously expressed lytic polysaccharide monooxygenase (PvLPMO9A) from Penicillium verruculosum. Biochim Biophys Acta Proteins Proteom. 2019. https://doi.org/10.1016/j.bbapap.2019.140297.

16. Singh RK, et al. Detection and characterization of a novel copperdependent intermediate in a lytic polysaccharide monooxygenase. Chem A Eur J. 2019. https://doi.org/10.1002/chem.201903562.

17. Zhang $R$, et al. Identification of a thermostable fungal lytic polysaccharide monooxygenase and evaluation of its effect on lignocellulosic degradation. Appl Microbiol Biotechnol. 2019;103(14):5739-50. https:// doi.org/10.1007/s00253-019-09928-3.

18. Arantes V, Goodell B. Current understanding of brown-rot fungal biodegradation mechanisms: a review. ACS Symp Ser. 2014;1158:3-21. https:// doi.org/10.1021/bk-2014-1158.ch001.

19. Wariishi H, Valli K, Gold MH. Manganese(II) oxidation by manganese peroxidase from the basidiomycete Phanerochaete chrysosporium: kinetic mechanism and role of chelators. J Biol Chem. 1992;267(33):23688-95. https://doi.org/10.1006/abbi.1998.0602.

20. Armbruster DA, Pry T. Limit of blank, limit of detection and limit of quantitation. Clin Biochem. 2008;29(Suppl 1):S49-52.

21. Kittl R, et al. Production of four Neurospora crassa lytic polysaccharide monooxygenases in Pichia pastoris monitored by a fluorimetric assay. Biotechnol Biofuels. 2012;5(1):79. https://doi.org/10.1186/1754-6834-5-79.

22. Loose JSM, et al. Activation of bacterial lytic polysaccharide monooxygenases with cellobiose dehydrogenase. Protein Sci. 2016;25(12):2175-86. https://doi.org/10.1002/pro.3043.

23. Simmons TJ, et al. Structural and electronic determinants of lytic polysaccharide monooxygenase reactivity on polysaccharide substrates. Nat Commun. 2017;8(1):1064. https://doi.org/10.1038/s41467-017-01247-3.

24. Bradford MM. A rapid and sensitive method for the quantitation of microgram quantities of protein utilizing the principle of protein-dye binding. Anal Biochem. 1976;72(1-2):248-54. https://doi.org/10.1016/00032697(76)90527-3.

\section{Publisher's Note}

Springer Nature remains neutral with regard to jurisdictional claims in published maps and institutional affiliations.

Ready to submit your research? Choose BMC and benefit from:

- fast, convenient online submission

- thorough peer review by experienced researchers in your field

- rapid publication on acceptance

- support for research data, including large and complex data types

- gold Open Access which fosters wider collaboration and increased citations

- maximum visibility for your research: over $100 \mathrm{M}$ website views per year

At BMC, research is always in progress.

Learn more biomedcentral.com/submissions 